\title{
PENGARUH PENUND AAN TAHAP PENUMPATAN DENGAN RESIN KOMPOSIT PADA TEKNIK SANDWICH TERHADAP KEKUATAN TARIK PELEKATAN SEMEN IONOMER KACA DAN RESIN KOMPOSIT
}

\section{Yulita Kristanti, Diatri Nari Ratih}

Bagian IImu Konservasi Gigi

Fakultas Kedokteran Gigi Universitas Gajah Mada

\begin{abstract}
Sandwich technique, a combination filling technique using composite resin filling material and glass ionomer cement has been widely used. In fact, such a combination filling technique need ffc $_{\mathrm{i}}$ longer time compare to filling without combination. This research was done in order to know the influence of delayed fill ; ing in sandwich technique using composite resin related to the tensile strength between glass ionomer cement and composite resin.

The materials studied consist of 16 samples, that were divided into 4 groups. The first one was used as the control groupt without delaying), while group II-IVwas used as the treating groups. Each group consist of 4 samples. The difference treatment between group II-IVwas the soaking time in the artificial saliva. Group II was soaked into artificial saliva ( $\mathrm{pH} 5)$ for 1 day, group , HI for 7 days, and group IVfor 14 days. The result of this research shows that the diference among the groups involved were very significant, except between group I and group II.The longer the sample was soaked into the artificial saliva, the tensile strength tends to decrease.
\end{abstract}

Key word: Sandwich technique,filling technique, composite resin 


\section{PENDAHULUAN}

Dewasa ini penggunaan resin komposit pada praktek kedokteran gigi semakin diminati. Hal ini oleh karena bahan ini memiliki beberapa kelebihan diantaranya : kekuatan tarik dan kekuatan tekan yang relatif besar, modulus elastisitas tinggi, kekerasan dan ketahanan terhadap abrasi yang cukup tinggi, tidak mudah larut, dan memiliki warna yang sangat mirip dengan warna gigi asli. Adapun kelemahannya, apabila bahan ini langsung diaplikasikan diatas dentin, monomer bahan tersebut dapat meresap dalam tubulus dentinalis. Jika hal initerjadi, maka akan menjadi ancaman $b^{\wedge}$ gi vitalitas jaringan pulpa. Oleh karena itu, sebelum ditumpat dengan resin komposit, digunakan semen ionomer kaca untuk memberikan perlindungan terhadap jaringan pulpa di bawahnya. Selanjutnya teknik ini disebut sebagai teknik sandwich. Menurut Mc Lean dan Wilson (1988) sandwich adalah restorasi yang menggunakan semen ionomer kaca tipe $\mathrm{H}$ dan resin komposit. Lebih lanjut Ferrari (1999) mengatakan bahwa pada jresinrasi sandwich, semen ionomer kaca digunakan untuk menggantikan dentin yang hilang, sedangkan email yang hilang digantikan oleh resin komposit.'-2

Hasil akhir dari teknik sandwich memang tampak jauh lebih baik dibandingkan tumpatan tunggal yang tidak dikombinasikan. Hal ini oleh karena kelemahan dari bahan tumpatan yang satu dapat dikompensasi oleh banah tumpatan yang lain. Salah satu konsekuensinya adalah waktu penangannya menjadi lebih panjang. Selama ini belum ada penelitian yang mencermati pengaruli penundaan satu tahap penumpatan pada teknik sandwich terhadap kekuatan pelekatan kedua bahan yang dikombinasikan tersebut. Penelitian ini dilakukan untuk mengetahui ada tidaknya pengaruh penundaan tahap penumpatan tersebut terhadap kekuatan tarik pelekatan diantara semen ionomer kaca resin komposit. 


\section{METODE}

Semen ionomer kaca merk Shofu diaduk menggunakan paper pad, dengan perbandingan sesuai dengan anjuran pabrik.Semen ionomer kaca yang sudah diaduk dimasukkan ke dalam 16 cetakan pertama yang sebelumnya telah diberi alas plastik dan diletakkan di atas pelat ihrca, uYfroncfrng, kemudian oYapfntasi sinar tampak selama 10 detik. Keenambelas sampel tersebut dibagi dalam 4 kelompok, masing-masing kelompok berisi 4 buah. Pada Kelompok I (Kontrol) setelah semen ionomer kaca yang telah dimasukkan dalam cetakan pertama dietsa selama 30 detik, ducuci dan dikeringkan, cetakan ke-

2 dipasang diatasnya dan bahan tumpatan resin komposit diisikan ke dalamnya sampai penuh. $\mathrm{Di}$ atasnya ditutup dengan pita plastik dan plat kaca, kemudian diberi beban seberat $0,5 \mathrm{~kg}$ selama 5 menit. Selanjutnya dilakukan penyinaran dengan sinar tampak seiama 40 detik, dengan jarak $4 \mathrm{~cm}$ dari sumber sinar, dibonding dan disinar lagi selama 10 detik.

Kelompok II sampai dengan kelompok IV, masing-masing juga terdiri dari 4 sampel. Pada kelompok II, semen ionomer kaca yang telah dimasukkan dalam cetakan pertama direndam dalam saliva buatan $\mathrm{pH} 5$ selama 1 hari, dan dimasukkan dalam inkubator $37^{\circ} \mathrm{C}$. Pada kelompok III dan IV lama perendamannya masingmasing 7 hari dan 14 hari.

Setelah dilakukan perendaman saliva sesuai dengan waktu yang telah ditentukan, sampel dikeringkan, dietsa 30 detik. Enambelas cetakan kedua disiapkan dan diletakkan di atasnya, kemudian resin komposit dimasukkan dalam cetakan tersebut sampai penuh dengan menggunakan plastis instrumen, ditutup plastik dan plat kaca dan diberi beban $0,5 \mathrm{~kg}$ selama 5 menit, kemudian disinar selama 40 detik,dibonding dan disinar lagi selama 10 detik.

Terakhir dilakukan pengukuran kekuatan tarik pelekatan semen ionomer kaca-resin komposit 
baik pada kelompok perlakukan

maupun pada kelompok kontrol.

\section{HASIL PENELITIAN DAN}

PEMBAHASAN

Fa6ei f. ffasiY Pengufcuran

Kekuatan Tarik Pelekatan Semen

lonomer Kaca Resin Komposit (kg).

\begin{tabular}{ccccc}
\hline \multicolumn{5}{c}{ Perlakuan } \\
\hline No & 1 hari & 7 hari & 14 hari & Kontrol \\
\hline 1 & 3.7 & 2.3 & 1.0 & 4.6 \\
2 & 3.5 & 2.5 & 1.0 & 3.7 \\
3 & 3.9 & 1.9 & 1.5 & 4.2 \\
4 & 3.6 & 2.0 & 0.9 & 3.9 \\
\hline
\end{tabular}

Tabel 2. Hasil Pengukuran Kekuatan Tarik Pelekatan Semen Lonomer Kaca Resin Komposit (Mpa)

\begin{tabular}{|c|c|c|c|c|c|}
\hline \multicolumn{6}{|c|}{ Perlakuan } \\
\hline No & 1 hari & 7 hari & 14 hari & Kontrol & \\
\hline 1 & 3,7 & 2.3 & 1.0 & 4.6 & \\
\hline 2 & 3,5 & 2.5 & 1.0 & 3.7 & \\
\hline 3 & 3.9 & 1.9 & 1.5 & 4.2 & \\
\hline 4 & 3.6 & 2.0 & 0.9 & 3.9 & \\
\hline Total & 20.38 & 12.07 & 6.11 & 22.75 & 61.31 \\
\hline$X$ & 5.095 & 3.02 & 1.53 & 5.69 & \\
\hline SB & \pm 024 & \pm 0.33 & \pm 0.27 & \pm 0.34 & \\
\hline
\end{tabular}


Tabel 3. Hasil Analisa Anova

\begin{tabular}{|c|c|c|c|c|c|c|}
\hline $\begin{array}{l}\text { Sumber } \\
\text { Variasi }\end{array}$ & $\mathrm{db}$ & JK & KT & Fhit $\frac{\mathrm{KT}_{\mathrm{P}}}{\mathrm{KT}}$ & FTabel 0.05 & Ftabel 0.01 \\
\hline Perlaku & 3 & 44.08 & 14.693 & 91.95 & 3.49 & 5.95 \\
\hline Error & 12 & 1.918 & 0.1598 & & & \\
\hline Total & 15 & 45.998 & & & & \\
\hline
\end{tabular}

Tabel I memperlihatkan hasil pengukuran kekuatan tarik pelekatan pada kelompok kontrol an kelompok perlakuan. Berdasarkan tabel tersebut, dapat diketahui besamya kekuatan tarik pelekatan dalam satuan Mpa, yang hasilnya tertera pada tabel II.

Dari tabel II terlihat baliwa rerata kekuatan tarik pelekatan terendah ditunjukkan pada kelompok dengan waktu perendaman 14 hari, yakni sebesar 1,53 Mpa, sedangkan kekuatan tarik pelekatan tertinggi pada kelompok perlakuan ditunjukkan pada kelompok dengan waktu perendaman 1 hari yakni sebesar 5,095 Mpa. Data-data tersebut selanjutnya dianalisis dengan menggunakan Anava 1 jam, yang hasilnya tertera pada tabel III.

Dari tabel III terlihat bahwa F hitung $=91,95$; sedangkan $\mathrm{F}$ tabel $(1 \%)=5,95$. Oleh karena $F$ hitung > $F$ tabel berarti ada perbedaan yang sangat bemiakna antar waktu perendaman.

Untuk mengetahui perbedaan antara kelompok yang satu dengan kelompok yang lain dilakukan dengan uji t.

Setelah data-data tersebut dibandingkan dengan tabel (1\%) terlihat bahwa hanya pada pengujian antara kelompok kontrol dengan kelompok yang direndam selama 1 hari saja yang tidak menunjukkan adanya perbedaan yang sangat bermakna. 
Tabel 4. Hasil Analisis dengan uji-t dari pengaruh variasi waktku perendanan terhadap kekuatan tarik perlekatan (Mpa)

\begin{tabular}{|l|c|c|c|c|}
\hline & $\mathrm{K}$ & 1 hari & 7 hari & 14 hari \\
\hline $\mathrm{K}$ & 0 & 0 & $*$ & $*$ \\
7 hari & & 0 & $*$ & $*$ \\
14 hari & & & 0 & $*$ \\
Db & & & & \\
$\mathrm{t}$ tabel & 16 & & & \\
& 3.707 & & & \\
\hline
\end{tabular}

Keterangan :

* $=$ terdapat perbedaan yang sangat bermakna

$0=$ tidak terdapat perbedaan .

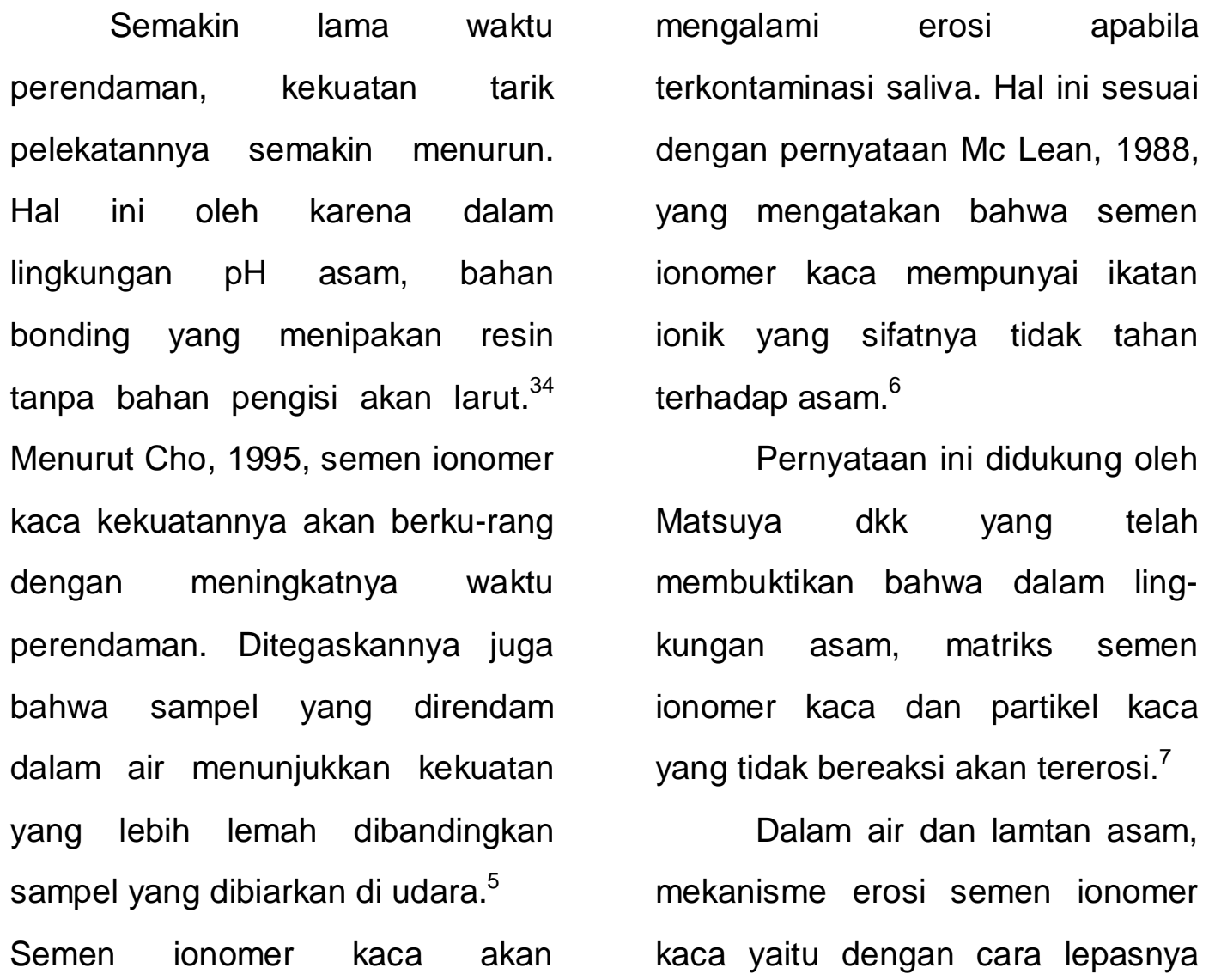


ion $\mathrm{Ca}^{2+}, \mathrm{Al}^{3+}, \mathrm{Si}^{2+}, \mathrm{F}^{\prime \prime}$ dan $\mathrm{Na}^{+}$. Erosi semen ionomer kaca ini dipengaruhi oleh kemampuan pembentukan kompleks antara ionion asam dengan kationkationlogam dan konsentrasi $\mathrm{H}^{+}$ pada pennukaan semen.

Permukaan yang mengalami erosi ini akan menjadi lebih kasar sehingga memudahkan udara terjebak di dalamnya. Keadan ini menurut Eick dkk, akan mengurangi efektivitas daerah permukaan tempat terjadinya tarik menarik. ${ }^{8}$

Walls dkk menyatakan bahwa banyaknya semen yang larut akan berkurang bila $\mathrm{pH}$ larutan asam naik. Dinyatakan juga bahwa ketahanan semen ionomer kaca selain dipengaruhi oleh waktu pengerasan juga dipengaruhi oleh $\mathrm{pH}$ larutan asam. ${ }^{9}$

Lebih lanjut Mc. Lean menjelaskan bahwa proses kelarutan semen ionomer kaca adalah oleh karena partikel kacanya mengandung alumina yang dapat memasuki jaringan silika, menggantikan silikon yang larut. Hal ini mendasari ketidaktahanan semen ionomer kaca terhadap serangan asam. ${ }^{6}$

\section{KESIMPULAN}

Dalam saliva buatan yang bersuasana asam, semen ionomer kaca dapat mengalami kelarutan, walaupun sudah dilindungi dengan bahan onding polimerisasi sinar tampak.Kelarutan semen ionomer kaca dalam suasana asam tersebut menyebabkan udara terjebak di dalamnya sehingga berpengaruh menurunkan kekuatan tarik pelekatannya. Makini lama waktu perendaman dalam saliva buatan, kekuatan tarik pelekatan akan makin rendah.

\section{DAFTAR PUSTAKA}

1. Mc. Lean, J. W. dan Wilson, A.D., 1988, Glass

2. Ionomer Cement, Quintessence Publishing Co., Inc., Chicago

3. Ferrari, M., 1999, Use of Glass lonomer Cement as Bondings, Linings or Bases dalam Carel C. Davidson dan Ivan A Mjor, Advances in Glass lonomer Cement, Quintessence 
Publishing Co. Inc., Chicago, 137-148.

4. Sam'an Malik, 1988, Pengamh Bonding Agent Dalam Menghalangi Terjadinya Kebocoran Marginal pada Restorasi Resin Komposit, dalam Naskah Lengkap Kursus Penyegar dan Penambah IImu Kedokteran Gigi VII, FKG-UI, Jakarta, 35-40.

5. Venz, S \& Kollmansperger, P., 1983, Compari-

6. son of the Physical Properties of Composite and Polishable Filling Resin, Quintessence Int: 14(2) :227-233

7. Cho, E., Kopel., H., dan White, SN., 1995, Moisture Susceptibility of Resin Modified Glass lonomer Materials, J. Quintessence Int., 26:351-358

8. Mc. Lean, JW, 1988, Glass Ionomer Cement, British Dent. J., 164:293-300.

9. Matsuya, S., Matsuya, Y., Yamamoto, Y, Yamane, 1984, Erosion of Glass lonomer Cement, Dent. Mat. J., 3(2) : 210219.
10. Eick, J.D., Johnson, LN., Fromer, JR., Good, RJ., and Neumann, AW., 972, Surface Topography : Its Influence on Wetting and Adhesion in Dental Adhesive System , J. Dent/ Res 51 (3):780-788.1

11. Walls, AWG., Mc Cabe., JF and Murray, JJ, 1988, The effect of the Variation $\mathrm{pH}$ of the Eroding Solution upon the Erotion Resistance of Glass Polyalkenoate (ionomer) Cements, British Dent.J., 164: 141-144 